Article

\title{
Tank Cascade Systems as a Sustainable Measure of Watershed Management in South Asia
}

\author{
Wiebke Bebermeier ${ }^{1, *}$, Julia Meister ${ }^{1}$, Chandana Rohana Withanachchi ${ }^{2}$, Ingo Middelhaufe ${ }^{1}$ \\ and Brigitta Schütt ${ }^{1}$ \\ 1 Department of Earth Sciences, Physical Geography, Freie Universität Berlin, Malteserstr. 74-100, \\ 12249 Berlin, Germany; j.meister@fu-berlin.de (J.M.); ingo.middelhaufe@fu-berlin.de (I.M.); \\ Brigitta.Schuett@fu-berlin.de (B.S.) \\ 2 Department of Archaeology and Heritage Management, Rajarata University of Sri Lanka, \\ 50300 Mihintale, Sri Lanka; chandanawithanachchi@gmail.com \\ * Correspondence: wiebke.bebermeier@fu-berlin.de, Tel.: +49-30-838-70873
}

Academic Editor: Tim Hess

Received: 16 January 2017; Accepted: 15 March 2017; Published: 22 March 2017

\begin{abstract}
In the dry zone of Sri Lanka, human-made reservoirs have served for the collection, storage and distribution of rainfall and runoff and provide irrigation water for the cultivation of paddy for 2000 years. This paper introduces the layout and function of four traditional village tank cascade systems in the hinterland of Anuradhapura, located in the North Central Province in Sri Lanka. In contrast to large-scale tanks, these systems are managed and maintained by local villagers. Sedimentological data from two tanks provide information about processes leading to the formation of these deposits and their post-sedimentary, partly human-induced alterations. The presented data support the hypothesis, that the decentral managed tanks were not affected by severe erosion after the abandonment of the ancient capital Anuradhapura in the 11th century CE, a period that was characterized by socio-economic instability and increased climatic fluctuations. Presented results underline the significance of small-scale tank cascades systems to buffer the effects of climatic fluctuations and point to their potential as a cornerstone in coping with future climate change in the dry zone of Sri Lanka.
\end{abstract}

Keywords: water harvesting; water storage; water control; traditional knowledge; tank siltation

\section{Introduction}

In the north-central dry zone of Sri Lanka, rainfall and surface runoff have been stored in human-made reservoirs since ancient times and today continue to provide water for irrigation [1]. During the two main rainy seasons in January-April and September-December, surface runoff is collected and stored in these reservoirs, the so-called tanks or wewas, and successively distributed during the dry periods to the paddy fields located downslope. The tanks are arranged in a cascade-like fashion along shallow valley courses. They are connected by canals and spillways and build a complex system of floodwater harvesting, water storage and water distribution [2].

The majority of these tanks were constructed during the period of the Anuradhapura kingdom (377 BCE to 1017 CE) [3], with its heyday characterized by the construction of new tanks and the reformation of existing tanks between 200 and 950 CE [4]. The introduction of this innovation was one of the most important preconditions for the development of early urban societies in north-central Sri Lanka, as knowledge of storage and distribution of water for irrigation purposes was necessary to obtain an agricultural surplus for the growing population and build the basis for the cropping of rice [5]. 
Today, 10,000 small so-called village tanks are still in use in the dry zone of Sri Lanka [6]. Besides irrigation, the stored water is used for domestic purposes, desiccated tank beds serve as pasture for the cattle [7] and deposited sediments are used as raw material for brick production [8]. Thus, the tanks have characterized the cultural landscape of north-central Sri Lanka for 2000 years, and have become an identity-generating factor for the rural everyday culture.

Today the tanks are classified into major, medium, minor and micro tanks depending on their water spread (water surface area of a tank) and command area (agricultural fields under irrigation). The responsibility for maintenance measures is shared between the Department of Irrigation (major and medium tanks) and the Department of Agrarian Services (minor and micro tanks) (Table 1) [9]. The ratio of tank command area (Acoa) to tank water-spread area (Awa) is a measure for the efficiency of tank cascade systems. For minor tanks, a ratio $\geq 1.0$ reflects a good balance between storage capacity and irrigated area [10].

Table 1. Classification of tank systems in South Asia and in the catchment of the Aruvi Aru basin, Sri Lanka (after Murray 2004, and literature cited herein).

\begin{tabular}{cccccc}
\hline Type & $\begin{array}{c}\text { Water-Spread } \\
\text { Area (ha) }\end{array}$ & $\begin{array}{c}\text { Command } \\
\text { Area (ha) }\end{array}$ & Maintenance & Seasonality & $\begin{array}{c}\text { Number of Tanks in } \\
\text { the Catchment of the } \\
\text { Aruvi Aru River * }\end{array}$ \\
\hline Major & $>200$ ha & $>600$ ha & State & Perennial & 11 \\
\hline Medium & $50-200$ ha & $80-60$ ha & State & $\begin{array}{c}\text { Perennial or } \\
\text { seasonal }\end{array}$ & 74 \\
\hline Minor & $1-50$ ha & $<80$ ha & $\begin{array}{c}\text { State and/or local } \\
\text { communities }\end{array}$ & Mostly seasonal & 150 \\
\hline Micro & $0.1-1$ ha & $<1$ ha & $\begin{array}{c}\text { Community or } \\
\text { individual farmers }\end{array}$ & $\begin{array}{c}\text { Perennial only with } \\
\text { ground supply }\end{array}$ & n.a. \\
\hline
\end{tabular}

Notes: * classification for the Aruvi Aru catchment, in which the study area is located, is based on the size of the water-spread area; n.a.: no information.

Historical records allow a tentative dating of early major irrigation works to the 3rd century BCE. In contrast, there is still a lack of data on the construction of minor tanks. Presumably, the construction of the village wewa systems developed from rain-fed agriculture [11,12]. As a result of wars and epidemics in the 14th century CE many major wewa systems fell into disrepair and were left abandoned [3]. In the 19th century, during the British colonial period, major ancient irrigation works were subsequently restored. After World War I, small village wewa systems also increasingly became the objects of restoration programs leading to a "stabilisation of the small tank irrigated agriculture" within the dry zone of Sri Lanka [13]. A broad store of traditional knowledge has been established over the centuries on the operation and maintenance of these systems [1,14], including strategies about how to deal with changing climatic conditions, for instance, during increased monsoonal variability in the Medieval Warm period and during the Little Ice Age [15]. This water-harvesting system in Sri Lanka is therefore regarded as a sustainable method that facilitates the capacity to support local communities in adapting to long-term changes in climate $[1,16]$.

Calculations of ecosystem services underline the present-day significance of the tank cascade systems for local communities. For the Kala Oya basin, these services account in total, including water supply, for c. US $\$ 2800$ per hectare per year, of which only US $\$ 160$ per hectare per year results from paddy cultivation. The remaining amount is derived from the utilization of tank water and tanks for vegetable, banana and coconut cultivation, fishery, the utilization of lotus roots and flowers, and the extraction of domestic, livestock and commercial water [17].

\subsection{Aims of the Paper}

Sustainable management of natural resources at watershed level is regarded as key to urban/rural balance [18]. In India, where comparable systems are in use for paddy irrigation, this balance is affected by the privatization of water resources, e.g., an increase in groundwater pumping by local water lords. 
The pumping leads locally to a decrease of groundwater levels and to the desiccation and abandonment of tanks. Not all community members are able to afford the costs for the pumped groundwater, triggering in the Indian state Tamil Nadu socio-economic segregation and migration processes [18]. This example illustrates the tight relationship between processes running at landscape level and socio-economic activities. Today, groundwater pumping in Sri Lanka has not yet reached a level affecting the function of tank cascade systems; however, as the surface near so-called regolith-aquifer in the central dry zone is predominantly recharged by the seepage of the tank beds, its increased exploitation would lead to an degradation of this important groundwater resource [19].

With a view to the coming decades, demographic and climatic changes, as well as changes in management responsibilities, may also affect and transform the ancient traditional water-harvesting systems in the northern dry zone of Sri Lanka. While today $77 \%$ of the total population (20.3 million in 2012) still live in rural areas, it is expected that in the coming decades more than half of the population will live in larger towns $[20,21]$ with the consequence of a loss of traditional knowledge concerning the maintenance and management of village tank cascade systems. According to the Intergovernmental Panel on Climate Change (IPCC) climate change scenarios, Sri Lanka will be affected by rising temperatures, a higher variability of monsoonal rainfall and an increase in climatic extreme events such as floods or droughts [20]. All of these developments have a potential to affect the future sustainable functionality and management of the water-harvesting and storage systems to an unknown extent.

Currently, potential future development trajectories and historical developments are investigated in an interdisciplinary joint research project between the Freie Universität Berlin and the University of Peradeniya, to provide stakeholders with a long-term series of data as base for the derivation of recommendations for actions. This study presents an inventory of selected, probably ancient tanks, which are until today predominantly traditionally managed and maintained by local villagers. In this sense, this paper contributes towards documenting the traditional layout of these systems, by introducing different sub-types of traditional village tank cascade systems located in the immediate vicinity of Anuradhapura, composed of minor and micro tanks, maintained by local villagers (Figure 1b).

Information about the construction dates of major irrigation works could be derived from literary, epigraphic and archaeological sources [22,23]. In contrast, little is known about the origin of smaller tanks and village tank cascade systems, which are considered as precursors of major irrigation works [13]. Hence, besides a documentation of the layout and function of traditional village tank cascades in the north-central dry zone of Sri Lanka, this paper presents sedimentological data from two connected minor tanks belonging to one of the investigated tank cascade systems. The results presented here contribute to improving understanding of processes leading to the formation of the deposits analyzed and their post-sedimentary, partly human-induced, alterations. Finally, the results support the hypothesis, that the investigated tank cascade system 2 was not affected by severe erosion after the abandonment of Anuradhapura in 1017 CE [4,24].

\subsection{Study Area}

The study area is located c. 1.7 to $4 \mathrm{~km}$ north of the fortified ancient center of Anuradhapura, the so-called Citadel (Figure 1). It comprises four valleys draining the slopes west of the Malwathu Oya River, a tributary to the Aruvi Aru River. Each of these valleys, like all other tributaries of the Malwathu Oya River in this region, was used for the construction of tank cascade systems. Climatically, the region corresponds to an As-climate according to the Köppen-Geiger classification [25], with annual mean temperatures of $27.1{ }^{\circ} \mathrm{C}$ and an annual average precipitation of $1198 \mathrm{~mm}$ [26]. High evapotranspiration rates foster water stress, especially during the period between May and September [27]. The bedrock is composed of metamorphic crystalline rocks, first of all charnockitic gneiss [28]. A near-surface aquifer at a depth of $2-10 \mathrm{~m} \mathrm{~b}$. s. is associated with the base of the regolith. A second aquifer corresponds to the deep fracture zone at a depth of $30 \mathrm{~m} \mathrm{~b}$. s. [29]. The study area is characterized by agriculture, where paddy rice is the primary cropping system. Vegetables are cultivated in a traditional slash-and-burn practice called chena cultivation [16]. 

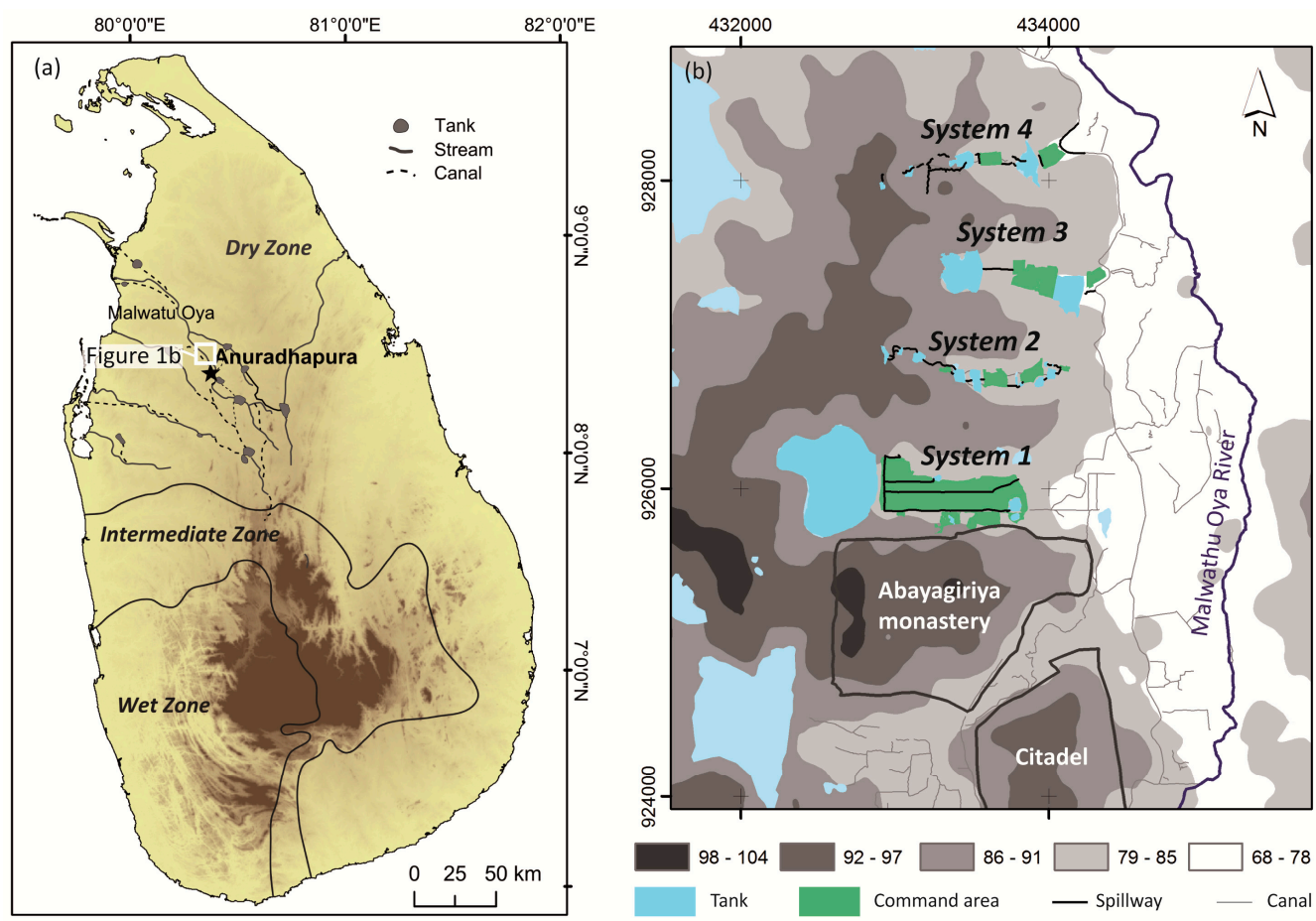

Figure 1. (a) Ancient irrigation system within the dry zone of Sri Lanka (modified after Seneviratna, 1987 [30]); (b) Location of the four investigated tank systems north of Anuradhapura.

\section{Material and Methods}

\subsection{Fieldwork and Data Processing}

The hydrological and infrastructural set-up of four tank cascade systems north of Anuradhapura was systematically mapped in the field in spring 2010 and autumn 2011 using a Garmin 60Cx handheld Global Positioning System (GPS) device. Field maps were digitized in a Geographical Information System (GIS) environment (ArcGIS 9.3, Environmental Systems Research Institute (ESRI)) and the ratio between command area (Acoa) and water-spread area (Awa) was calculated. Three sediment cores were extracted from two subsequent tanks of a tank cascade system (system 2), located ca. $2.5 \mathrm{~km}$ north of the ancient city center (Figure 1b; Table 2). Drillings were carried out using percussion drilling equipment (Wacker hammer, BHF 30S, Wacker Neuson Group Munich). All core sections were extracted in closed plastic tubes, $5 \mathrm{~cm}$ in diameter.

Table 2. Drilling characteristics.

\begin{tabular}{cccc}
\hline \multirow{2}{*}{ Sediment Profile } & UTM * East & UTM * North & Depth (cm) \\
\cline { 2 - 3 } & \multicolumn{3}{c}{$\mathbf{( 4 4 N )}$} \\
NA01 & 433,520 & 926,767 & 250 \\
NA02 & 433,547 & 926,702 & 180 \\
NA03 & 433,458 & 926,740 & 300 \\
\hline
\end{tabular}

Note: * Universal Transverse Mercator (UTM).

\subsection{Sediment Analysis}

Deposits of small tanks were affected by multiple post-sedimentary alterations, driven by natural and anthropogenic factors. Results from a study carried out c. $30 \mathrm{~km}$ east of the study area indicate the low suitability of these deposits for a high-resolution reconstruction of paleo-environmental conditions [16]. Based on this, laboratory analysis was limited to the determination of sediment texture and accelerator mass spectrometry (AMS) radiocarbon dating. 
Sediments were macroscopically described in the laboratory, recording grain size and lithostratigraphy, carbonate and organic content, moisture, texture, rooting, hydromorphic and special features (e.g., macro plant remains or calcite concretions). Two-centimeter-thick bulk samples were taken at $10 \mathrm{~cm}$ intervals and according to stratigraphic layers. After removal of the fraction $>2 \mathrm{~mm} \varnothing$, grain size distribution was determined with a laser diffraction particle size analyzer (LS 13320 PIDS, Beckmann-Coulter Germany, Krefeld, Germany) following the methodological set-up as described in Schütt et al., 2013 [16].

Four bulk samples of organic sediments were sent for AMS radiocarbon dating to the Poznan radiocarbon laboratory, Poland. Pretreatment of AMS radiocarbon samples comprised the manual removal of visible roots. Calibration was conducted with OxCal 4.2 [31] applying the calibration curve IntCal13 [32].

\section{Results}

\subsection{Micro-To-Minor-Scale Tank Cascade Systems North of Anuradhapura}

The tank cascade systems recorded are located north of the Citadel of Anuradhapura. In the undulating terrain, a slightly inclining, eastward-facing slope is drained by several first-order tributaries running W-E to the Malwathu Oya River, located in a sequence with a distance of $1.5 \mathrm{~km}$. An N-S-striking ridge of outcropping bedrock forms the divide in the headwater area of the tank cascade systems. An archaeological survey within the catchment of system 2 yielded numerous archaeological findings especially in its headwater area. Finds such as bricks, pottery, tiles, stone steps and stone cuttings indicate settlement and quarrying activity during prehistoric and historical times [33].

The most southern system, system 1, consists of only a single tank, 31 ha in size (Figure 2a). The water of this tank is used to irrigate a paddy field, located directly downstream of the tank. Three spillways, constructed as shallow canals, dug in the soil, are used to distribute the irrigation water through the paddy fields. A village is situated north of the paddy field. A small strip between the paddy field and village, as well as small patches north and west of the tank, are used for chena cultivation. The described setting is surrounded by an open deciduous forest. The Acoa/Awa ratio totals 0.8 .
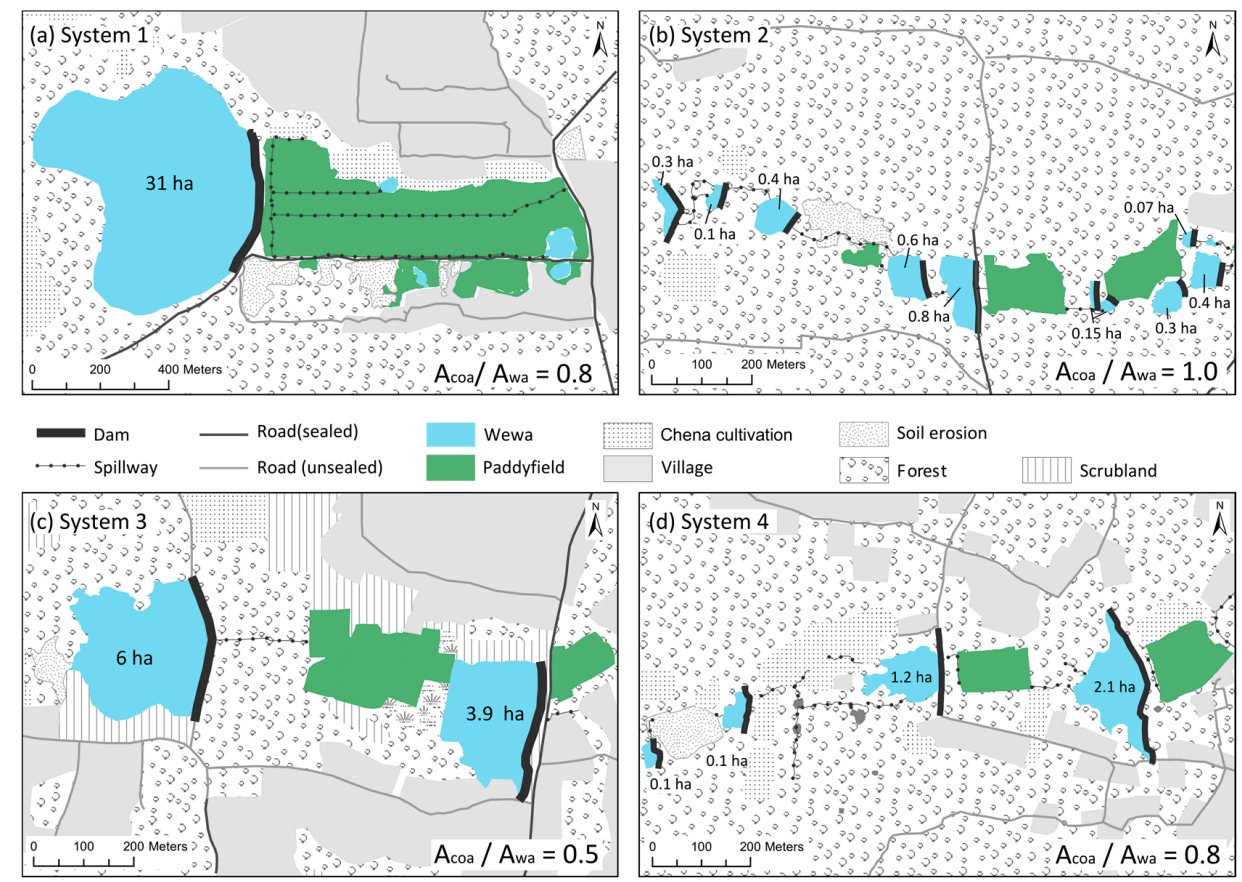

Figure 2. Sketches $(\mathbf{a}-\mathbf{d})$ show the layout of four tank cascade systems north of Anuradhapura (a) system 1 ; (b) system 2; (c) system 3; (d) system 4. ( $\mathrm{A}_{\text {coa }}$ : water-spread Area, $\mathrm{A}_{\text {wa }}$ : water-spread area). 
System 2 connects north to system 1; it comprises ten active tanks and one inactive tank, which are aligned in a row (Figure $2 b$ ). The western divide is formed by a linear bedrock outcrop (Figure 3a). All tanks are classified as micro tanks as their water-spread areas are smaller than 1 ha, ranging in size between 0.07 ha and 0.8 ha (Figure 3b). Spillways and sluices (Figure 3c) connect the tanks. Paddy field cultivation is the prevailing agricultural land use found along the thalweg (Figure 3e). Three paddy fields are associated with the active tanks. In contrast, a fourth paddy field, located west of tank 4, is not connected to a tank and is instead cultivated on a rain-fed basis. Chena cultivation is practiced mainly in the headwater area of the drainage basin. Areas which are not utilized for agriculture are covered by shrubs or forests (Figure 3f). Increased soil degradation and erosion has occurred predominantly between tanks 4 and 5 in an area where there are repeated cattle drives (Figure 3c). The Acoa/Awa ratio of system 2 totals 1.0.
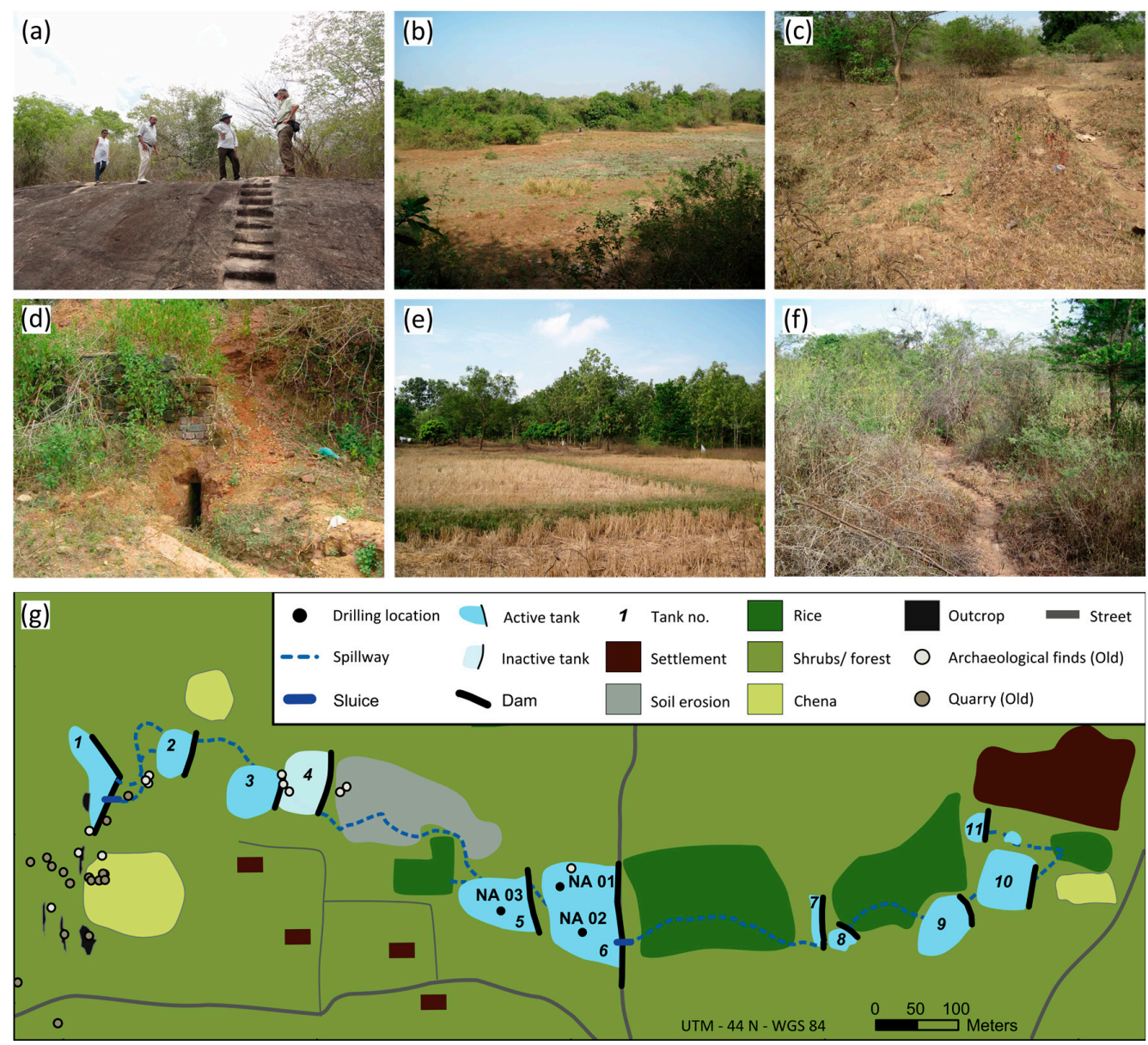

Figure 3. Detailed set-up and characteristics of system 2: (a) bedrock outcrop, with sculptured stairs as the western boundary of tank 1 ; (b) view from the dam of tank 6 into the desiccated water-spread area; (c) area affected by soil erosion; (d) sluice of tank 6; (e) paddy field between tank 6 and tank 7; (f) shallow earthen spillway connecting tank 4 and tank 5 surrounded by scrubland; (g) detailed layout of system 2 , showing the bedrock outcrops in the headwater area, distribution of archaeological findings and the location of sediment profiles NA01-NA03.

Tank cascade system 3 is characterized by two tanks of 6.0 ha and 3.9 ha in size (Figure 2c). The water is routed from the first tank via a spillway $150 \mathrm{~m}$ through an open deciduous forest to a paddy field. Two villages located north and south of the W-E-striking thalweg frame this system. At the fringe of the northern village, the open deciduous forests degrade into scrubland. West of the northern village, an area is used for slash-and-burn cultivation. The Acoa/Awa ratio totals 0.5. 
Tank system 4 comprises four tanks, connected in a linear series (Figure 2d). The tank size increases downstream from 0.1 ha to 2.1 ha. Downslope of tank 1 , local soil erosion occurs. Downslope of tank 1 and upstream from tank 3 , the land use along the thalweg is dominated by chena cultivation. In contrast, downstream of tank 3, paddy fields occur along the thalweg east of the tank dams. In accordance with the systems already introduced, system 4 is also embedded in a cultural landscape with open deciduous forests and villages. The Acoa/Awa ratio totals 0.8.

\subsection{Sediment Characteristics of the Tanks in System 2}

The occurrence of archeological artifacts in the headwater area of system 2 points to (pre)historic human activities in this area. Due to this clear indication of human impact, the tanks of system 2 were selected for sedimentological analysis. In order to receive an integral indication of processes related to runoff and sediment balance as influenced by climate and human activities, two drillings were carried out in tank 6 (NA01, NA02). A third drilling (NA03) was conducted in tank 5 immediately upstream of tank 6 . In the following, the lithostratigraphy of the drillings is briefly described.

\subsubsection{Sediment Profile NA01}

In the upper periphery of tank 6, approximately 50 m west of its dam, drilling NA01 was conducted, extracting $250 \mathrm{~cm}$ of undisturbed sediments. The sediments of NA01 are not stratified and consist of loamy, sandy and gravely material (Figure 4). Corresponding to their macroscopic character, the sediments are subdivided into six units (Table 3). Underlying units VI and V comprise the basal section of profile NA01 $(170-250 \mathrm{~cm} \mathrm{~b}$. s.), which is represented by the saprolite with unweathered fragments of quartz and feldspars. The superimposing units I-IV $(1-170 \mathrm{~cm} \mathrm{b.} \mathrm{s.)}$ are characterized by fine-grained sediments of allochtonous origin. The uppermost centimeter of the sediment profile consists of undecomposed plant remains. The sediment color lightens from top to bottom, changing from dark brown to olive and pale brown to yellowish/white. Throughout the whole profile, sesquioxide oxidation marks and concretions in different sizes occur frequently. Calcite precipitation appears as fine distributed powder and coatings.

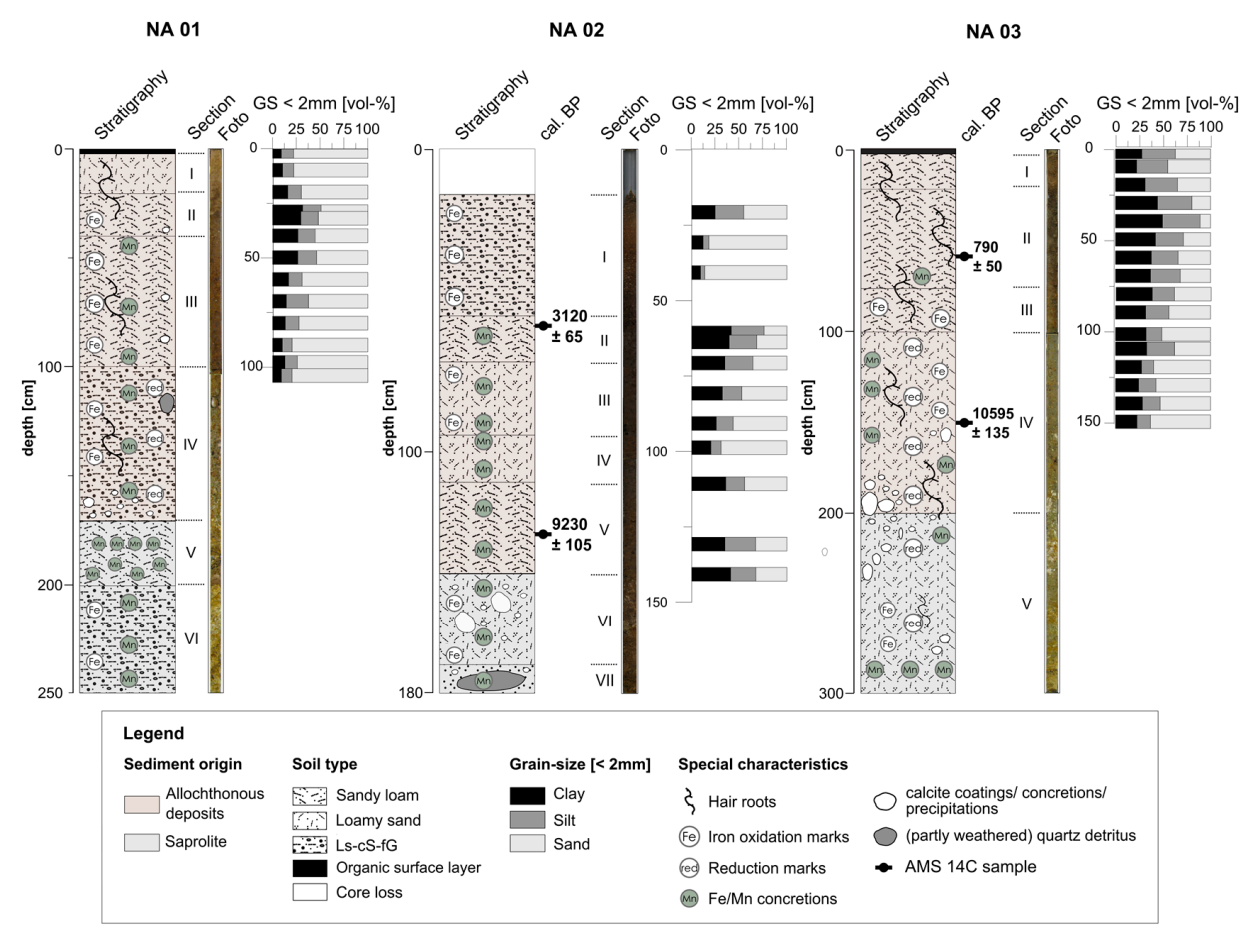

Figure 4. Lithostratigraphy of sediment profiles NA01, NA02 (tank 6) and NA03 (tank 5) in system 2. 
Table 3. Sediment characteristics drilling NA01.

\begin{tabular}{|c|c|c|}
\hline Unit & Depth (cm b. s.) & Sediment Character \\
\hline & $0-1$ & litter, undecomposed plant remains \\
\hline$I^{*}$ & $1-20$ & $\begin{array}{l}\text { loamy sand with sub-angular fine gravel, dark yellowish brown (10 YR } \\
4 / 6 \text { ), moderately rooted (hair roots), dry, unconsolidated, gradual change to }\end{array}$ \\
\hline $\mathrm{II}^{*}$ & $20-40$ & transitional horizon between units I and II, gradual change to \\
\hline III * & $40-100$ & $\begin{array}{l}\text { sandy loam, dark brown ( } 7.5 \text { YR } 3 / 4) \text {, weakly rooted (hair roots), fairly dry, } \\
\text { highly compacted, mottled sesquioxide oxidation marks, scattered } \\
\text { calcareous precipitations and coatings, scattered Fe/Mn concretions (small), } \\
\text { diffuse change to }\end{array}$ \\
\hline $\mathrm{IV}^{*}$ & $100-170$ & $\begin{array}{l}\text { angular-shaped gravel in sandy loamy-matrix, olive brown }(2.5 \mathrm{YR} 4 / 4 \text {, } \\
\text { reduced), isolated hair roots, moist, highly compacted, mottled sesquioxide } \\
\text { oxidation marks, scattered Fe/Mn concretions, scattered calcareous } \\
\text { precipitations, diffuse change to }\end{array}$ \\
\hline $\mathrm{V} * *$ & $170-210$ & $\begin{array}{l}\text { alternating layers of sandy and loamy material, sand: yellow }(10 \text { YR } 8 / 6) \text { to } \\
\text { very pale brown }(10 \text { YR } 8 / 4) \text {, clay: dark yellowish brown }(10 \text { YR } 4 / 6) \text {; not } \\
\text { rooted, moist, highly compacted, very high concentration of small } \\
\text { sesquioxide concretions at depths from } 178 \text { to } 181 \mathrm{~cm} \text {, scattered calcareous } \\
\text { precipitations, diffuse change to }\end{array}$ \\
\hline $\mathrm{VI} * *$ & $210-250$ & $\begin{array}{l}\text { sandy/gravely (angular-shaped), very crumbly, yellowish/white in color, } \\
\text { not rooted, moist, highly compacted, scattered Fe/Mn concretions, } \\
\text { scattered sesquioxide oxidation marks }\end{array}$ \\
\hline
\end{tabular}

Notes: * allochtonous deposits; ${ }^{* *}$ saprolite.

\subsubsection{Sediment Profile NA02}

Profile NA02 was extracted $60 \mathrm{~m}$ south of profile NA01 in tank 6 . The extracted sediment sequence totals $180 \mathrm{~cm}$. Based on macroscopic sediment characters, seven units can be distinguished (Table 4, Figure 4). Due to compaction processes during drilling, the uppermost $18 \mathrm{~cm}$ of the drill tube were empty. The topmost sediment unit $\mathrm{I}(18-55 \mathrm{~cm})$ consists of fine gravel in a sandy matrix. The texture of units II-VI ( $55-170 \mathrm{~cm}$ b. s.) is predominated by sandy loam. The lowermost unit VII $(170-180 \mathrm{~cm} \mathrm{b.} \mathrm{s.)}$ is characterized by middle and coarse sand with a small amount of angular-shaped fine gravel. Units VI and VII correspond to saprolite, while the superimposing units I-V correspond to allochtonous sediments. Sediments are not stratified and are all over dark brownish in color. Sesquioxide concretions and oxidation marks occur frequently along the profile, while calcium carbonate precipitations and coatings are found in the deeper sediment sequences $(140-180 \mathrm{~cm} \mathrm{b.} \mathrm{s.).}$

Table 4. Sediment characteristics drilling NA02.

\begin{tabular}{ccl}
\hline Unit & Depth (cm b. s.) & \multicolumn{1}{c}{ Sediment Character } \\
\hline $0-18$ & core loss \\
\hline I * & $18-55$ & $\begin{array}{l}\text { fine gravel in sandy matrix; structure-less; very weakly compacted; } \\
\text { colored gradation from dark greyish brown (10 YR 4/2) over dark } \\
\text { brown (10 YR 4/4) to dark yellowish brown (10 YR 3/3); dry but } \\
\text { increasing moisture with greater depth, strong sesquioxide oxidation } \\
\text { marks; weakly rooted (hair roots), clear change to }\end{array}$ \\
\hline II * & $55-70$ & $\begin{array}{l}\text { sandy loam; very dark brown (10 YR 2/2); not rooted; moist; highly } \\
\text { compacted, scattered Fe/Mn concretions, diffuse change to }\end{array}$ \\
\hline III * & $70-93$ & $\begin{array}{l}\text { ditto unit II; mottled sesquioxide oxidation marks; scattered Fe/Mn } \\
\text { concretions, diffuse change to }\end{array}$ \\
\hline IV * & $93-110$ & $\begin{array}{l}\text { sandy loam; dark yellowish brown (10 YR 4/4); not rooted; moist; } \\
\text { highly compacted; weak sesquioxide oxidation marks, diffuse change to }\end{array}$ \\
\hline
\end{tabular}


Table 4. Cont.

\begin{tabular}{|c|c|c|}
\hline Unit & Depth (cm b. s.) & Sediment Character \\
\hline $\mathrm{V}^{*}$ & $110-140$ & $\begin{array}{l}\text { sandy loam (getting coarser with increasing depth); dark yellowish } \\
\text { brown (10 YR 3/6); not rooted; moist; highly compacted; yellow } \\
\text { streaks of sesquioxide oxidation marks; scattered Fe/Mn concretions } \\
\text { (spherical, Ø } 1 \mathrm{~cm}) \text {, diffuse change to }\end{array}$ \\
\hline $\mathrm{VI} * *$ & $140-170$ & $\begin{array}{l}\text { coarse sandy loam (becoming coarser with increasing depth); dark } \\
\text { yellowish brown (10 YR 3/6); not rooted; moist; highly compacted; } \\
\text { soft calcium carbonate precipitations and coatings (light brownish grey, } \\
10 \text { YR 6/3, very crumbly); scattered small Fe/Mn concretions, } \\
\text { diffuse change to }\end{array}$ \\
\hline VII ** & $170-180$ & $\begin{array}{l}\text { middle and coarse sand with a small amount of angular-shaped fine } \\
\text { gravel; very crumbly; dark yellowish brown ( } 10 \mathrm{YR} 4 / 6) \text {; decrease of } \\
\text { calcium carbonate precipitations; increase of Fe/Mn concretions; } \\
\text { not rooted; moist; highly compacted; partly weathered quartz } \\
\text { detritus from } 175 \text { to } 180 \mathrm{~cm} \text { depth }\end{array}$ \\
\hline
\end{tabular}

Notes: * allochtonous deposits; ${ }^{* *}$ saprolite.

\subsubsection{Sediment Profile NA03}

Sediment profile NA03 was extracted from tank 5 approximately $35 \mathrm{~m}$ upstream of the dam and comprises $300 \mathrm{~cm}$ of undisturbed sediments. Corresponding to their macroscopic character, the sediments are subdivided into five sedimentological units (Table 5), which are classified in two main sediment sections: the highly weathered, saprolitic base of this profile is represented by unit $\mathrm{V}$ (200-300 cm b. s.), whereas the overlying sediment units IV to I are composed of unlayered loamy, sandy and gravely allochtonous material (Table 5). The uppermost $2 \mathrm{~cm}$ of the profile consists of organic litter. Sediment colors become brighter with increasing depth, changing from dark brown at the top to yellowish/pale brown at the bottom of the sediment profile. Sesquioxide oxidation marks and concretions, as well as calcium carbonate precipitations occur frequently as non-cured, fine, distributed powder.

Table 5. Sediment characteristics drilling NA03.

\begin{tabular}{|c|c|c|}
\hline Unit & Depth (cm b. s.) & Sediment Character \\
\hline & $0-2$ & litter, organic overlay \\
\hline$I^{*}$ & $2-21$ & $\begin{array}{l}\text { loamy (coarse) sand with small contents of fine gravel; dark yellowish } \\
\text { brown (10 YR } 4 / 4) \text {; moderately rooted (hair roots); dry; highly } \\
\text { compacted, gradual change to }\end{array}$ \\
\hline II * & $21-75$ & $\begin{array}{l}\text { sandy loam with small contents of fine gravel; dark greyish brown } \\
\text { (10 YR 3/2); weakly rooted (hair roots); scattered Fe/Mn concretions } \\
\text { (spherical, <Ø } 0.5 \mathrm{~cm} \text { ); dry; highly compacted, diffuse change to }\end{array}$ \\
\hline $\mathrm{III}$ * & $75-100$ & $\begin{array}{l}\text { coarse sandy loam with fine gavel; very dark greyish brown } \\
\text { (10 YR 3/2); weakly rooted; dry; very highly compacted; mottled } \\
\text { sesquioxide-oxidation marks; many Fe/Mn concretions, clear change to }\end{array}$ \\
\hline IV * & 100-200 & $\begin{array}{l}\text { coarse sandy loam; olive brown ( } 2.5 \mathrm{YR} 4 / 4) \text {; weakly rooted (hair roots); } \\
\text { moist; highly compacted; scattered Fe/Mn concretions (up to Ø } 1 \mathrm{~cm} \text { ); } \\
\text { sesquioxide-oxidation marks; soft diffuse calcium carbonate } \\
\text { precipitations, diffuse change to }\end{array}$ \\
\hline $\mathrm{V}^{* *}$ & $200-300$ & $\begin{array}{l}\text { mixed horizon of layers of coarse sandy loam with fine gravel and } \\
\text { sand with sesquioxide oxidation marks; sandy loam: olive brown } \\
\text { ( } 2.5 \text { YR 4/4), sand: yellow ( } 10 \text { YR } 8 / 6) \text { \& very pale brown ( } 10 \text { YR } 8 / 4) \text {; } \\
\text { very weakly rooted (hair roots); moist; moderate to highly compacted; } \\
\text { scattered Fe/Mn concretions; soft diffuse calcium } \\
\text { carbonate precipitations }\end{array}$ \\
\hline
\end{tabular}

Notes: * allochthones deposits; ${ }^{* *}$ saprolite. 


\subsubsection{AMS Radiocarbon Dating}

The chronology of profiles NA02 and NA03 is based on four AMS radiocarbon dates, corresponding to two dates for each drilling. The dates are stratigraphically consistent and range between 10,595 and $790 \mathrm{cal}$ a BP. Overall, they provide a Holocene chronology for the sediment sequences. The youngest age appears in sediment profile NA03 (sample Poz-37935, 57-58 cm b. s.) and dates to the period immediately after the abandonment of Anuradhapura in 1017 CE (Table 6). In both sediment profiles, two ages related to the early Holocene are found in sediments overlying the saprolite (NA02, Poz-40252; NA03 Poz-40249).

Table 6. AMS radiocarbon dates.

\begin{tabular}{cccccc}
\hline $\begin{array}{c}\text { Sediment } \\
\text { Profile }\end{array}$ & Lab-Code & $\begin{array}{c}\text { Sampling Depth } \\
\text { (cm b. s.) }\end{array}$ & $\begin{array}{c}\text { Uncalibrated } \\
\text { Age (a BP) }\end{array}$ & $\begin{array}{c}\text { Calibrated Age } \\
\text { (cal a BP, 2 } \mathbf{~})\end{array}$ & $\begin{array}{c}\text { Calibrated Age } \\
\text { (cal a BCE/CE, 2 } \mathbf{~} \text { ) }\end{array}$ \\
\hline NA02 & Poz-40251 & $59-60$ & $2960 \pm 40$ & $3120 \pm 65$ & $1170 \pm 65 \mathrm{BCE}$ \\
NA02 & Poz-40252 & $147-149$ & $8250 \pm 70$ & $9230 \pm 105$ & $7285 \pm 105 \mathrm{BCE}$ \\
NA03 & Poz-37935 & $57-58$ & $870 \pm 30$ & $790 \pm 50$ & $1160 \pm 50 \mathrm{CE}$ \\
NA03 & Poz-40249 & $146-147$ & $9370 \pm 80$ & $10595 \pm 135$ & $8645 \pm 135 \mathrm{BCE}$ \\
\hline \multicolumn{6}{c}{ Note: * Before Present (BP). }
\end{tabular}

\section{Discussion}

\subsection{Layout of the Tank Cascade Systems}

The four tank cascade systems that underwent analysis are associated with the type of linear cascades in which all tanks are aligned in a row [10]. The number of tanks per cascade varies between one and eleven. The investigated tank cascade systems are situated in first-order, shallow saucer-shaped valleys, which are regarded as not being prone to erosion. Consequently, the geomorphological conditions of the study area seem to have favored the construction and sustainable function of these systems. All systems provide irrigation water for paddy cultivation west of the floodplain of the Malwathu Oya River (Figure 1b).

The tanks are embedded in a cultural landscape setting, which is regarded as typical for village tank cascade systems. In an idealized model, this setting is composed of four concentrically arranged zones, namely the tank, the paddy fields, the settlement areas and the surrounding shrub lands and forests [34]. Each of these zones fulfills specific functions and is traditionally used for different purposes. All four zones are represented in the investigated tank cascade systems. In the following, local particularities are briefly discussed.

During both field campaigns in April 2010 and September 2011, the majority of tanks, except the single tank in system 1 , were desiccated, reflecting weather conditions during previous months, with an unusually dry rainy season in spring 2010 and the end of the dry season in September 2011.

Various observations like soil erosion and damage to the dams and sluices indicated that the maintenance measures were neglected. Cultivation of rice or other plants with high temporal water consumption is known to be a local form of subsequent use of desiccated tank bodies [9,35]. However, due to the prohibition of the cultivation of tank bodies by the government, this phenomenon could not be observed in the study area $[7,9,35]$. In contrast, the traditional use of desiccated tank beds as pasture during the dry season is still practiced in the four systems investigated.

A typical feature of village tank ecosystems is a wetland area, called thaulla in Sinhala, which can be found upstream of the tank body at the root of the discharging channel. Runoff and channeled irrigation water from upstream tanks pass this swampy area in which aquatic plants force the deposition of fines [36]. Such thaulla areas could not be identified for the investigated tank cascade systems. It is assumed that the intensive irrigation agriculture causes relatively quick consumption of the stored water, which in turn prevents the development of an upstream wetland. In addition, due to increased population pressure, thaulla areas have been increasingly removed from all over Sri Lanka's dryland zone during the last decades [35]. 
Desiltation of tanks is practiced regularly by local villagers as a maintenance measure to sustain the storage capacity of the tanks [16]. The extracted sediments are utilized as raw material for bricks or as fertilizer for the fields [13]. Revisiting system 2 in 2014 and interviews with local villagers showed that sediments had in the recent past also been illegally exploited using heavy machinery and utilized as construction material (Figure 5) (personal interview with a local villager, 23 September 2015) [37]. This practice affects the functionality of the tank cascade system as the deepening of the tank bed lead to an exposure of the surface near regolith aquifer. Consequently, this tank bed does not fall dry anymore and cannot be used as pasture during the dry season.
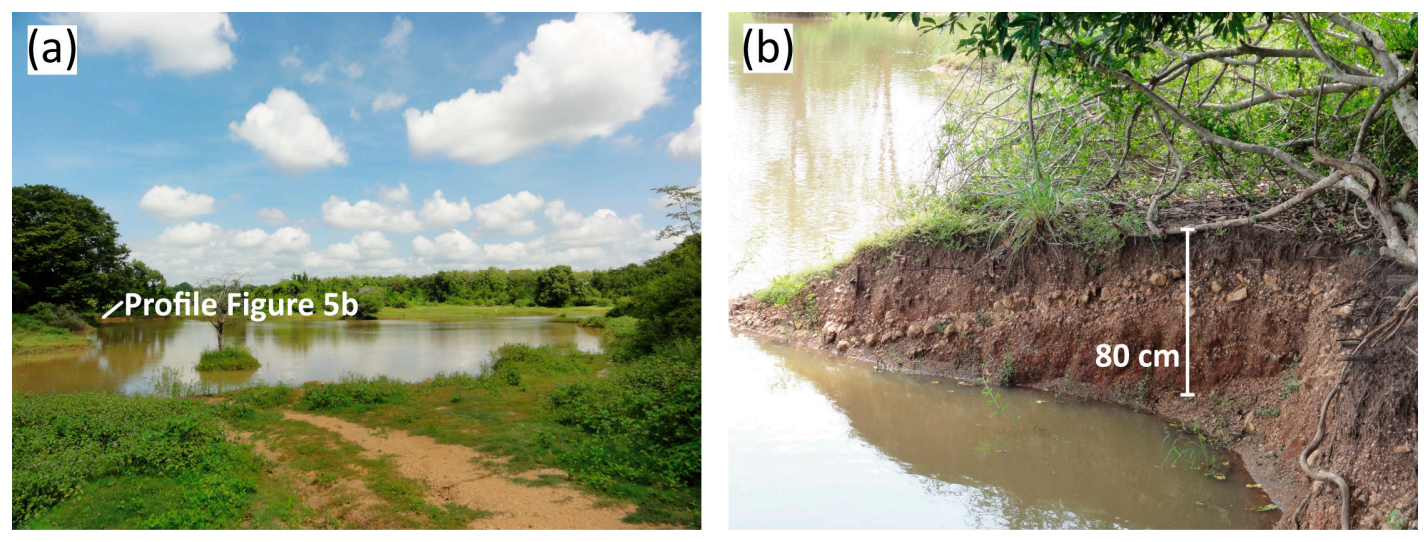

Figure 5. Photographs of tank 6, system 2 taken from the tank bund in October 2014. (a) The central part of the tank was illegally dredged; (b) c. $80 \mathrm{~cm}$ of sediments, or saprolite, were extracted. The deepening of the tank beds leads to the exposure of the regolith aquifer. Consequently, the tank bed does not desiccate in the dry period, resulting in a loss of pastures.

The ratio of tank command area (Acoa) to tank water-spread area (Awa) is a measure for the efficiency of tank cascade systems. Ideally, this ratio should be $\geq 1.0$ in order to provide enough storage capacity for irrigation [10]. With a ratio of 1.0, this optimal condition is only present in system 2.

The north-central dry zone of Sri Lanka is characterized by a dispersed settlement pattern. This pattern is also reflected in the distribution of settled areas in the investigated tank cascade systems, in which various small settled areas occur. In all systems, settled areas are situated in close vicinity to tanks and the associated paddy fields. Archaeological findings in system 2 indicate a (pre)historic utilization of this area [33]. Chena cultivation, a slash-and-burn practice, is applied in all systems. It is widely assumed that the beginning of shifting cultivation dates prior to the onset of paddy cultivation. To intersperse chena cultivation with irrigation-based rice cropping is typical for the dry zone in Sri Lanka and is practiced until today ([38] and literature cited herein). Remarkable is the chena cultivation in the command area of tank 2 in system four, as traditionally this slash-and-burn practice is not based on irrigation.

All investigated tank systems, with the associated agricultural fields and settlement areas, are embedded in open deciduous forests or scrubland, which are utilized as pasture for cattle and for logging. A distinction between parkland and forested areas as proposed by Tennakoon could not be observed [34].

\subsection{Sediment Characteristics}

Sediment texture and macroscopic sediment character are used as proxies to differentiate between allochtonous sediments and the autochthonous weathered bedrock (saprolite) [16]. The weathering grade of the parent metamorphic bedrock is locally highly heterogeneous, resulting from the petrographic character and small scale changes in environmental conditions [39-41]. The transition between saprolite and superimposing allochtonous deposits is characterized in profiles NA01 and 
NA03 by a diffuse change from gravels in a matrix of sandy loam to alternating layers of sandy and loamy material at a depth of $170 \mathrm{~cm} \mathrm{b.} \mathrm{s.} \mathrm{(profile} \mathrm{NA01)} \mathrm{and} 200 \mathrm{~cm} \mathrm{b.} \mathrm{s.} \mathrm{(profile} \mathrm{NA03).} \mathrm{In} \mathrm{profile}$ $\mathrm{NA} 02$, the saprolite was identified at a depth of $140 \mathrm{~cm} \mathrm{~b}$. s. based on a diffuse change from sandy loam to coarse sandy loam. A distinct boundary as described in a previous study about tank sediments in the Anuradhapura district was not observed in the extracted sediments [42].

Two different types of sediment facies can be expected to overlie the in-situ weathered saprolite: Facies (a) is associated with fluvial deposits in an alluvial plain dating to a phase prior to tank construction, and facies (b) is expected to be characterized by siltation in the still water body of the tanks [42]. Tank sediments can be assumed to be of varying origin due to human impact, such as soil erosion in consequence of tillage or cattle watering [43]; furthermore, this material may also result from erosional processes at the slopes. In a previous study, the sand/(silt + clay) ratio was successfully applied as a proxy to characterize the introduced facies for tanks in the Anuradhapura district ranging in size between 23 ha and 15 ha [42]. Contrastingly, in the present study it was not possible to distinguish between the two facies by this proxy. Another study on tank sediments c. $30 \mathrm{~km}$ east of Anuradhapura showed that consideration of bulk chemical and physical sediment parameters like electric conductivity, $\mathrm{pH}$-value, total organic and inorganic carbon, chemical parameters and magnetic susceptibility also do not enable a differentiation between autochthonous saprolite and allochtonous sediments to be made [16]. This might be attributed to the relatively small size of tanks investigated. Tanks 5 and 6 have an area $<1$ ha; unlike larger tanks they desiccate throughout the dry season and are affected by tropical soil formation processes [44,45]. A resulting textural degradation of layering as well as the mixture of chemical composition, especially within the uppermost meter, is primarily caused by bioturbation by plant roots, micro-organisms and soil fauna as well as pediturbation due to the shrinking and swelling of clays and their translocation in desiccation cracks [45].

The precipitation of carbonates and the frequent occurrence of oxidation and reduction marks reflect regular changes of hydromorphous conditions associated with the periodical desiccation of the tanks [46]. The occurrence of calcite concretions is a common feature in the soils of the dry zone [47]. Dissolved calcium originating from the weathering of feldspars is transported laterally in the subsoil, gets enriched and precipitates as calcareous concretion in the poorly drained soils of the valley bottom, receiving its carbonates from conversion of $\mathrm{CO}_{2}$-containing soil water [48]. Reduction and oxidation marks in profiles NA01 and NA03 indicate seasonal variations of the groundwater table [44]. Precipitation of sesquioxide is an indicator for oxidizing processes linked with the desiccation of the tanks [49]. Other factors affecting sedimentation conditions and post-sedimentary alteration of the tank deposits are related to the above-mentioned traditional subsequent use of the desiccated tanks during the dry season as paddy fields, livestock pasture or a source for construction material. Furthermore, the desiltation of tanks leads to a considerable removal of material out of the reservoirs, which is also reflected in the hiatus of younger sediments.

\subsection{Geochronology}

Carbon from bulk sediment samples originating from tank sediments was used for radiocarbon dating, as extracted sediments did not contain macro plant remains or charcoal. Here the different origins of the dated carbon, e.g., soil organic matter and-in the context of lake sediments-old-carbon reservoirs (e.g., shales, bedrock), need to be taken into account [50]. Soil organic matter is regarded as a product of continuous processes of accumulation and decomposition [51]. Resulting AMS ages are therefore frequently interpreted as minimum ages for soil formation [52,53]. Dating of carbon from old reservoirs is associated with the "hardwater effect" leading to an overestimation of resulting ages $[50,53,54]$. As carbonaceous bedrock is absent in the study area, and carbonates precipitation corresponds to a secondary precipitation of carbonates, it is concluded that the calcites found are authigenic or correspond to remnants of organisms like shells or bones [55]. Additional sources for errors, resulting in an underestimation of ages, may include a vertical relocation of humic acids, an incomplete removal of roots or rootlets and bioturbation [56,57]. Ages measured are in stratigraphic 
order and match the pattern presented for a comparable system $30 \mathrm{~km}$ east of Anuradhapura [16]. Taking the uncertainties mentioned into account, the ages provide a rough Holocene chronology for the introduced profiles.

\subsection{Synthesis}

The tank cascade systems are deeply interwoven in the socio-economy and landscape household in the central dry zone of Sri Lanka. In this paper, the layout and function of four traditional village tank cascade systems is presented. The results contribute to a documentation of this traditional water-harvesting technique, which built the foundation for irrigation agriculture not only in the dry zone of Sri Lanka, but also in South India since several hundred years. Furthermore, an analysis of tank sediments allows conclusions on the buffering capacity of tank cascade systems against past socio-economic developments (e.g., the abandonment of the ancient capital of Anuradhapura) and climate changes.

Abandoned land management systems have a tendency to shift from depositional into erosional environments after the neglect or cessation of maintenance measures [58,59]. Such a transition is not reflected in the sedimentological record from tank cascade system 2. The radiocarbon sample Poz-37935 dating to 1110-1210 CE (profile NA03) matches with the period after the abandonment of Anuradhapura in 1017 CE (Table 6). Although the city lost its status as capital of the Anuradhapura kingdom, archaeological evidence indicates a continuation of the occupation and use of its hinterland [60]. It is reported for this period that reservoirs and canals were affected by siltation and fell partly into disuse [61]. Climatically, this phase corresponded to the Medieval Warm Period, characterized in South Asia by alternating intervals of stronger and weaker monsoonal intensities [15]. This increase in climatic dynamics is also not reflected in the sedimentological record of profile NA03, as there is a lack of coarser detritus corresponding to more dynamic depositional environments. In summary, the sediment facies dated to 1110-1210 CE clearly indicates siltation processes in a depositional environment. This could be tentatively interpreted as evidence, that these decentral managed tanks were not affected by severe erosion during a period, which was characterized by socio-economic instability and increased climatic fluctuations. The presented results underline the significance of small-scale tank cascades to buffer effects related to climatic fluctuations. Despite being exposed to fluctuations of monsoonal intensities and socio-economic change and facing periods of decay, e.g., in the 14th century CE [3], they have been in use for some 2000 years and continue to meet a variety of water demands in the north-central dry zone of Sri Lanka. The integration of traditional techniques and knowledge in planning their future sustainable development has great potential to anchor these systems as a cornerstone in coping with future climate change scenarios.

Acknowledgments: We thank the anonymous reviewers for their very valuable remarks and advice, which substantially helped to improve the paper. Numerous project partners, students and sponsors supported this study. First of all, we would like to thank Kay Kohlmeyer, Hochschule für Technik und Wirtschaft for inviting us in the framework of his project "Ausgrabungen an der Zitadelle von Anuradhapura (Sri Lanka)" funded by the Gerda Henkel Stiftung. The Department of Earth Sciences, Freie Universität Berlin co-funded fieldwork in 2010. The tank cascade systems north of Anuradhapura were mapped in the framework of an interdisciplinary geoarchaeological summer school funded by the Volkswagen Foundation. We kindly thank the participating students from the Rajarata University of Mihintale, Sri Lanka, and the Freie Universität Berlin, Department of Earth Sciences for supporting the fieldwork. We are grateful to Thusitha Wagalawatta, Department of Archaeology, Colombo. We thank the Volkswagen Foundation for granting a joint research project between the Freie Universität Berlin and the University of Peradeniya (Project-ID: 88578) named "Tank cascade systems as ancient measure of integrated Watershed Managements in the dry zone of Sri Lanka", which allows us to continue joint research on the water harvesting system in Sri Lanka.

Author Contributions: All authors contributed equally to this research work.

Conflicts of Interest: The authors declare no conflict of interest. 


\section{References}

1. Withanachchi, S.S.; Köpke, S.; Withanachchi, C.R.; Pathiranage, R.; Ploeger, A. Water resource management in dry zonal paddy cultivation in Mahaweli River Basin, Sri Lanka: An analysis of spatial and temporal climate change impacts and traditional knowledge. Climate 2014, 2, 329-354. [CrossRef]

2. Jayatilaka, C.J.; Sakthivadivel, R.; Shinogi, Y.; Makin, I.W.; Witharana, P. A simple water balance modelling approach for determining water availability in an irrigation tank cascade system. J. Hydrol. 2003, 273, 81-102. [CrossRef]

3. Zubair, L. Modernisation of Sri Lanka's Traditional Irrigation Systems and Sustainability. Sci. Technol. Soc. 2005, 10, 161-195. [CrossRef]

4. Gilliland, K.; Simpson, I.A.; Adderley, W.P.; Burbidge, C.I.; Cresswell, A.J.; Sanderson, D.C.W.; Coningham, R.A.E.; Manuel, M.; Strickland, K.; et al. The dry tank: Development and disuse of water management infrastructure in the Anuradhapura hinterland, Sri Lanka. J. Archaeol. Sci. 2013, 40, 1012-1028. [CrossRef]

5. Deraniyagala, S.U. The Prehistory of Sri Lanka, 2nd ed.Department of Archaeological Survey: Colombo, Sri Lanka, 1992.

6. Dahdouh-Guebas, F.; Hettiarachchi, S.; Seen, D.L.; Batelaan, O.; Sooriyarachchi, S.; Jayatissa, L.P.; Koedam, N. Transitions in ancient inland freshwater resource management in Sri Lanka affect biota and human populations in and around coastal lagoons. Curr. Boil. 2005, 15, 579-586. [CrossRef] [PubMed]

7. Leach, E.R. Village irrigation in the dry zone of Sri Lanka. In Irrigation and Agricultural Development in Asia: Perspectives from the Social Sciences; Cornell University Press: Ithaca, NY, USA, 1980; pp. 91-126.

8. Dharmasena, P.B. Conservation farming practices for small reservoir watersheds: A case study from Sri Lanka. Agrofor. Syst. 1994, 28, 203-212. [CrossRef]

9. Murray, F. Potential for Aquaculture in Community-Managed Irrigation Systems of the Dry-Zone, Sri Lanka: Impacts on Livelihoods of the Poor. Ph.D. Thesis, University of Stirling, Stirling, UK, 2004.

10. Sakthivadivel, R.; Fernando, N.; Panabokke, C.R.; Wijayaratna, C.M. Nature of Small Tank Cascade Systems and a Framework for Rehabilitation of Tanks within Them; International Irrigation Management Institute (IIMI): Colombo, Sri Lanka, 1996.

11. Amarasinghe, U.S.; Nguyen, T.T.T. Enhancing rural farmer income through fish production: Secondary use of water resources in Sri Lanka and elsewhere. In Success Stories in Asian Aquaculture; De Silva, S.S., Davy, F.B., Eds.; Springer: Dordrecht, The Netherlands, 2010; pp. 103-130.

12. Jyothi, V.; Panabokke, C.R. Evolution of the indigenous village irrigation systems of Sri Lanka. Econ. Rev. 2010, 3-9. Available online: http://dl.nsf.ac.lk/bitstream/handle/1/14112/ER-36-\%281-2\%29_3.pdf?sequence=2 (accessed on 16 January 2017).

13. Panabokke, C.R.; Sakthivadivel, R.; Weerasinghe, A.D. Evolution, Present Status and Issues Concerning Small Tank Systems in Sri Lanka; International Water Management Institute Colombo (IWMI): Colombo, Sri Lanka, 2002.

14. Geekiyanage, N.; Pushpakumara, D.K.N.G. Ecology of ancient Tank Cascade Systems in island Sri Lanka. J. Mar. Isl. Cult. 2013, 2, 93-101. [CrossRef]

15. Sinha, A.; Cannariato, K.G.; Stott, L.D.; Cheng, H.; Edwards, R.L.; Yadava, M.G.; Ramesh, R.; Singh, I.B. A 900-year (600 to $1500 \mathrm{ad}$ ) record of the Indian summer monsoon precipitation from the core monsoon zone of India. Geophys. Res. Lett. 2007, 34, 1-5. [CrossRef]

16. Schütt, B.; Bebermeier, W.; Meister, J.; Withanachchi, C.R. Characterisation of the Rota Wewa tank cascade system in the vicinity of Anuradhapura, Sri Lanka. Die Erde J. Geogr. Soc. Berl. 2013, 144, 51-68.

17. Russi, D.; ten Brink, P.; Farmer, A.; Badura, T.; Coates, D.; Förster, J.; Kumar, R.; Davidson, N. The Economics of Ecosystems and Biodiversity for Water and Wetlands; IEEP: London, UK; Brussels, Belgium, 2013.

18. Gunnell, Y.; Krishnamurthy, A. Past and Present Status of Runoff Harvesting Systems in Dryland Peninsular India: A Critical Review. AMBIO J. Hum. Environ. 2003, 32, 320-324. [CrossRef]

19. Panabokke, C.R.; Perera, A.P.G.R.L. Groundwater Resources of Sri Lanka; Water Resource Board: Colombo, Sri Lanka, 2005.

20. National Climate Change Adaptation Strategy \& Supporting Documents. Available online: http://www. climatechange.lk/adaptation/Index.html (accessed on 16 January 2017). 
21. Department of Census and Statistics—Sri Lanka: Population and Housing. Available online: http://www. statistics.gov.lk/page.asp?page=Population\%20and\%20Housing (accessed on 16 January 2017).

22. Risberg, J.; Myrdal-Runebjer, E.; Miller, U. Sediment and soil characteristics and an evaluation of their applicability to the irrigation history in Sigiriya, Sri Lanka. J. Nord. Archaeol. Sci. 2002, 13, 27-42.

23. Perera, L.S. The Sources of Ceylon History. In History of Ceylon; De Silva, K.M., Ed.; Ceylon University Press: Colombo, Sri Lanka, 1959; Volume 1, pp. 46-74.

24. Lucero, L.J.; Fletcher, R.; Coningham, R. From 'collapse' to urban diaspora: The transformation of low-density, dispersed agrarian urbanism. Antiquity 2015, 89, 1139-1154. [CrossRef]

25. Kottek, M.; Grieser, J.; Beck, C.; Rudolf, B.; Rubel, F. World map of the Köppen-Geiger climate classification updated. Meteorol. Z. 2006, 15, 259-263.

26. Food and Agriculture Organization of the United Nations Clim. FAOClim World-Wide Agroclimatic Data, Version 2.01; Working Paper 5; Environment and Natural Resources; Food and Agriculture Organization of the United Nations (FAO): Rome, Italy, 2001.

27. Panabokke, C.R.; Sakthivadivel, R.; Weerasinghe, A.D. Evolution, Present Status and Issues Concerning Small Tank Systems in Sri Lanka; International Water Management Institute (IWMI): Colombo, Sri Lanka, 2008.

28. Somasekaram, T. The National Atlas of Sri Lanka; Sri Lanka Survey Department: Colombo, Sri Lanka, 1988; pp. 1-141.

29. Panabokke, C.R.; Ariyaratne, B.R; Seneviratne, A.; Wijekoon, D.; Molle, F. Characterization and Monitoring of the Regolith Aquifer within four Selected Cascades (Sub-watersheds) of the Malala Oya Basin; International Water Management Institute: Colombo, Sri Lanka, 2007.

30. Seneviratne, A. The Hydraulic Civilization of the Ancient Rajarata in Sri Lanka; International Water Management Institute (IWMI): Colombo, Sri Lanka, 1987.

31. Ramsey, C.B.; Lee, S. Recent and planned developments of the program OxCal. Radiocarbon 2013, 55, 720-730. [CrossRef]

32. Reimer, P.J.; Bard, E.; Bayliss, A.; Beck, J.W.; Blackwell, P.G.; Bronk Ramsey, C.; Buck, C.E.; Cheng, H.; Edwards, R.L.; Friedrich, M.; et al. IntCal13 and Marine13 radiocarbon age calibration curves 0-50,000 years cal BP. Radiocarbon 2013, 55, 1869-1887. [CrossRef]

33. Mendis, D.T.; Abeywardana, N.; Withanachchi, C.R. An Archaeological Study to Identify the Ancient Settlement Pattern of Anuradhapura with Special Reference to the "Deegapasana" Rock Outcrop in Sri Lanka; Nihal Printers: Kurunegala, Sri Lanka, 2016; (original publication in Sinhala).

34. Tennakoon, M.U.A. Rural Settlement and Land Use in North Central Sri Lanka. Ph.D. Thesis, Syracuse University, New York, NY, USA, 1974.

35. Mahatantila, K.; Chandrajith, R.; Jayasena, H.A.H.; Ranawana, K.B. Spatial and temporal changes of hydrogeochemistry in ancient tank cascade systems in Sri Lanka: Evidence for a constructed wetland. Water Environ. J. 2008, 22, 17-24. [CrossRef]

36. Chandrajith, R.; Mahatantila, K.; Jayasena, H.A.H.; Tobschall, H.J. Geochemical characteristics of sediments from a reservoir (tank) ecosystem in Sri Lanka. Paddy Water Environ. 2008, 6, 363-371. [CrossRef]

37. Personal interview with a local villager, 23 September 2015 in the village Palugaswewa, Sri Lanka. Personal communication, 2015.

38. Kingwell-Banham, E.; Fuller, D.Q. Shifting cultivators in South Asia: Expansion, marginalisation and specialisation over the long term. Quat. Int. 2012, 249, 84-95. [CrossRef]

39. Hewawasam, T. Tropical weathering of apatite-bearing rocks of Sri Lanka: Major element behaviour and mineralogical changes. J. Geol. Soc. Sri Lanka 2013, 15, 31-46.

40. Hewawasam, T.; von Blanckenburg, F.; Bouchez, J.; Dixon, J.L.; Schuessler, J.A.; Maekeler, R. Slow advance of the weathering front during deep, supply-limited saprolite formation in the tropical Highlands of Sri Lanka. Geochim. Cosmochim. Acta 2013, 118, 202-230. [CrossRef]

41. Behrens, R.; Bouchez, J.; Schuessler, J.A.; Dultz, S.; Hewawasam, T.; von Blanckenburg, F. Mineralogical transformations set slow weathering rates in low-porosity metamorphic bedrock on mountain slopes in a tropical climate. Chem. Geol. 2015, 411, 283-298. [CrossRef]

42. Dharmasena, P.B. Magnitude of sedimentation in village tanks. Trop. Agric. 1992, 148, 97-120.

43. Thiemann, S.; Schütt, B.; Förch, G. Assessment of erosion and soil erosion processes-A case study from the Northern Ethiopian Highland. FWU Water Resour. Publ. 2005, 3, 173-185. 
44. Panabokke, C.R. Soil Science: The Soils of Ceylon and Use of Fertilizers; Ceylon Association for the Advancement of Science, Metro Printers: Colombo, Sri Lanka, 1967; pp. 1-151.

45. Young, A. Tropical Soils and Soil Survey; Cambridge University Press: Cambridge, UK, 1980; Volume 9.

46. Schütt, B. Zum holozänen Klimawandel der zentralen Iberischen Halbinsel. Relief Boden Palaeoklima 2004, 20, 1-347.

47. Panabokke, C.R. A study of some soils in the Dry Zone of Ceylon. Soil Sci. 1959, 87, 67-74. [CrossRef]

48. Schütt, B.; Busschert, R. Geomorphological reconstruction of palaeo Lake Ashengi Northern Ethiopia. In Proceedings of the Lake Abaya Research Symposium 2004, Siegen, Germany, 10-12 November 2004; Förch, G., Ed.; Forschungsinstitut Wasser und Umwelt (FWU): Siegen, Germany, 2005; pp. 51-57.

49. Schütt, B. The chemistry of playa-lake-sediments as a tool for the reconstruction of Holocene environmental conditions-A case study from the central Ebro basin. In Paleoecology of Quaternary Drylands; Smykatz-Kloss, W., Felix-Henningsen, P., Eds.; Springer: Berlin/Heidelberg, Germany, 2004; pp. 5-30.

50. Nambudiri, E.M.V.; Teller, J.T.; Last, W.M. Pre-quaternary microfossils-A guide to errors in radiocarbon dating. Geology 1980, 8, 123-126. [CrossRef]

51. Wang, Y.; Amundson, R.; Trumbore, S. Radiocarbon dating of soil organic matter. Quat. Res. 1996, 45, 282-288. [CrossRef]

52. Dreibrodt, S.; Lubos, C.; Hofmann, R.; MÜLler-ScheeßEl, N.; Richling, I.; Nelle, O.; Fuchs, M.; Rassmann, K.; KujundŽIĆ-VejzagiĆ, Z.; Bork, H.R.; et al. Holocene river and slope activity in the Visoko Basin, Bosnia-Herzegovina-Climate and land-use effects. J. Quat. Sci. 2013, 28, 559-570. [CrossRef]

53. Grimm, E.C.; Jacobson, G.L. Late-Quaternary vegetation history of the eastern United States. In The Quaternary Period in the United States; Gillespie, A.R., Porter, S.C., Atwater, B.F., Eds.; Elsevier: Amsterdam, The Netherlands, 2003; Volume 1, pp. 381-402.

54. Lowe, J.; Lowe, S.; Fowler, A.J.; Hedges, R.E.; Austin, T.J. Comparison of accelerator and radiometric radiocarbon measurements obtained from Late Devesian Lateglacial lake sediments from Llyn Gwernan, North Wales, UK. Boreas 1988, 17, 355-369. [CrossRef]

55. Schütt, B.; Thiemann, S.; Weneclawiak, B. Deposition of modern fluvio-lacustrine sediments in Lake Abaya, south Ethiopia-A case study from the delta areas of Bilate River and Gidabo River, northern basin. Geomorph. NF 2005, 138, 131-151.

56. Possnert, G. Radiocarbon dating by the accelerator technique. Nor. Archaeol. Rev. 1990, 23, 30-37. [CrossRef]

57. Premathilake, R. Relationship of environmental changes in central Sri Lanka to possible prehistoric land-use and climate changes. Palaeogeogr. Palaeoclimatol. Palaeoecol. 2006, 240, 468-496. [CrossRef]

58. Beckers, B.; Schütt, B. The chronology of ancient agricultural terraces in the environs of Petra. In Men on the Rocks: The Formation of Nabataean Petra; Mouton, M., Schmid, S., Eds.; Logos Verlag: Berlin, Germany, 2013; Volume 1, pp. 313-322.

59. Beckers, B.; Schütt, B.; Tsukamoto, S.; Frechen, M. Age determination of Petra's engineered landscape-Optically stimulated luminescence (OSL) and radiocarbon ages of runoff terrace systems in the Eastern Highlands of Jordan. J. Archaeol. Sci. 2013, 40, 333-348. [CrossRef]

60. Coningham, R.; Gunawardhana, P. Anuradhapura: The Hinterland; Archaeopress for the Society for South Asian Studies: Oxford, UK, 2013.

61. Brohier, R.L. Ancient Irrigation in Ceylon; Government Press: Colombo, Sri Lanka, 1934.

(c) 2017 by the authors. Licensee MDPI, Basel, Switzerland. This article is an open access article distributed under the terms and conditions of the Creative Commons Attribution (CC BY) license (http:/ / creativecommons.org/licenses/by/4.0/). 